Article

\title{
Optimizing the Cooperated "Multi-Countries" Biodiesel Production and Consumption in Sub-Saharan Africa
}

\author{
Tito Francisco Ianda ${ }^{1}$ (D), Emerson Andrade Sales ${ }^{1}$, Ademar Nogueira Nascimento ${ }^{1}$ \\ and Antonio Domingos Padula ${ }^{2, *(D)}$ \\ 1 UFBA Escola Politécnica da UFBA Programa de Pós-graduação em Engenharia Industrial, \\ Universidade Federal da Bahia, PEI/UFBA. Rua Prof Aristídes Novis, 02-Federação, \\ CEP 40210-610 Salvador-BA, Brazil; titoianda@yahoo.com.br (T.F.I.); \\ andradesales.emerson@gmail.com (E.A.S.); annas@ufba.br (A.N.N.) \\ 2 UFRGS Escola de Administração, Programa de Pós-Graduação em Administração, \\ Universidade Federal do Rio Grande do Sul, PPGA/UFRGS. Rua Washington Luis, 855, \\ CEP 90010-460 Porto Alegre-RS, Brazil \\ * Correspondence: adpadula@ea.ufrgs.br; Tel.: +55-51-3308-3536
}

Received: 9 July 2020; Accepted: 8 September 2020; Published: 10 September 2020

\begin{abstract}
Sub-Saharan African countries present chronic energy shortages and heavy reliance on oil imports for diesel. The small demand and high production costs in some countries have compromised the economic feasibility of the biodiesel industry in the region. Therefore, to overcome these limitations a model of "multi-countries" cooperated production and consumption of biodiesel was proposed for a group of seven neighboring countries. The model explored linear programming and simulations to the problem of minimizing biodiesel production costs considering different types of production and demand restrictions. The data processing was realized using the Solver and Linear Interactive Discrete Optimizer software (LINDO). The simulations and scenarios revealed that palm oil is the crop that minimize the production costs (US\$0.82/L) and that, although jatropha was classified in the second place (US\$1.05/L), it is the crop with the biggest job creation potential (5.0 times that of the palm oil seeds). These results reveal the presence of a trade-off in the strategy and the choice between different oilseeds: (a) to produce biodiesel from the crop with minimal costs (palm oil) or (b) to choose the one that has the biggest potential for job creation (jatropha). Considering the diesel price between US $\$ 0.60$ and US\$1.14/L at service stations in the region in 2016, both the biodiesel from palm oil and jatropha will need subsidies and fiscal incentives (tax reductions) to be competitive in the fuel market (diesel). The volume of biodiesel to supply the B10 demand in 2031 has the potential to reduce US\$ 1.98 billion/year of the expenses on oil imports. It is worth observing that this decision-support model adds the "multi-countries" cooperation perspective as a contribution to the methodological and political approaches about biofuels production and consumption and can be exploited as a starting point for the formulation of policies, strategies, and investment decisions for the establishment of biodiesel production programs.
\end{abstract}

Keywords: biodiesel production; multi-countries cooperation; decision-support model; linear programming; scenario analysis; trade-off

\section{Introduction}

Sub-Saharan Africa (SSA) comprises 47 countries located south of the Sahel region. These countries have distinct characteristics in terms of agricultural culture and food but have very similar agroclimatic conditions. These countries are characterized by extreme poverty, chronic energy deficits, and a high 
dependence on oil imports. The United Nations report [1] pointed out that 1.2 billion people in the world do not have access to energy. In 2019, this number was almost 1 billion people (600 million in SSA), while 2.7 billion people (853 million in SSA) still use only the energy from firewood and biomass for heating and cooking, which causes forest devastation and land degradation in these regions [2], the majority being in Southeast Asia and SSA. The countries with the greatest difficulties are Guinea-Bissau, Burundi, and Liberia, where the shortage of conventional energy affects between $88 \%$ and $97 \%$ of the inhabitants [3].

The growth in fossil fuel consumption had a great boost in the first half of the 20th century in the region, a period when oil was considered an infinite resource, subsidized, and offered at low prices. During this period, demand was inelastic, enabling the development of infrastructure and transportation based on the consumption of oil products. SSA countries planned their respective developments based on this premise, becoming vulnerable during oil supply crises due to the absence of energy alternatives and dependence on the import of this fuel $[4,5]$. To meet the energy demand, SSA countries spend a large part of their reserve in foreign currency on importing oil to obtain energy to generate electricity through thermoelectric power plants, land transport, and agriculture. Research on the dependence on oil imports by countries in the sub-Saharan region identifies, for example, that Côte d'Ivoire spends $13 \%$ of its foreign exchange on oil imports and that this proportion increases to $14 \%$ in Guinea-Bissau, $17 \%$ in Burkina Faso, and more than $23 \%$ in Zimbabwe, negatively impacting the trade balance of these countries [6].

There is a significant association between development and access to energy-the more developed a country is, the greater its energy consumption to meet population demand and the productive base [7]. The need to expand access to energy from renewable sources is already recognized as fundamental to the development and economic growth of countries. However, it must occur sustainably and as cleanly as possible, in order to mitigate the negative effects of using domestic biomass [8]. It is understood, therefore, that it is strategic to develop energy and oil alternatives that are sustainable for this region of Africa. The production and use of liquid biofuels can also contribute to strengthening the economy of these countries, reducing spending on oil imports, and contributing to the promotion of socio-economic development in the region $[2,9,10]$. Among the energy options with the potential for production in SSA (wind, solar, biogas, biofuels, hydraulic, and geothermal), biofuels have great potential in this region, due to the ease of access to production technologies, the intense involvement of agricultural systems in the production of raw materials, and the predominance of agriculture as an activity that generates jobs and income for the population of these countries.

Most of the demand for biofuels is in South Africa, while neighboring countries (Tanzania and Mozambique) have the highest biomass productivity and available land [11,12]. Several countries in sub-Saharan Africa have developed biofuel production initiatives in recent years, aiming to reduce demand for oil and ensuring energy security [13]. The predominant technology in the production of biodiesel in the region is first-generation, which consists of the transesterification of vegetable oil to produce biodiesel, using anhydrous ethanol or methanol as reagents and caustic soda as a catalyst. However, SSA's regional bioenergy production initiatives, based on liquid biofuels of plant origin, mainly biodiesel, have faced major barriers related to high production costs, low agricultural productivity, and a low production scale in this region [14-20]. Studies on the production of biofuels in the sub-Saharan region reveal a great diversity of demand for biodiesel and the availability of land for the cultivation of oilseeds. Some countries have a high demand for biodiesel and less land availability, while several others have a very low demand for biodiesel and greater availability of land. These imbalances have limited the economic viability of biodiesel production chains in this region $[14-16,19,20]$. Thus, this study explores the perspective and the opportunity to propose and simulate alternatives for cooperative production configurations among the countries of this region. The design, proposal, and implementation of policies, strategies, and projects for cooperative production and consumption of biodiesel between various countries in the region can be an alternative to reverse this situation, making economic scales of production and consumption of this biofuel 
viable. To carry out this initiative of "multi-countries" cooperative production and consumption of biodiesel, the modeling of biodiesel production systems to support the process of formulating policies and deciding on the investments, location, volumes, and viability of the production systems is necessary.

The expansion of the share of renewable sources in the energy matrix has been strongly encouraged worldwide in recent decades and various methods and modeling approaches have been explored to evaluate the alternatives and feasibility of renewable energy production systems. Reviewing the literature about models used to support decision-making on renewable energies, Ilbahar et al. [21] identified that multi-attribute decision-making (MADM) methods have been widely used to evaluate energy policies and investments, selection of renewable energy sources, and the identification of the optimal site for a renewable energy facility. Balaman and Selim [22] explored a fuzzy optimization approach to find the optimum configuration of renewable energy supply chains integrating biomass-based renewable energy and district heating systems (DHS). Their model "combines cost and service level objectives and accounts for biomass supply, material flow, capacity demand and technical constraints". A general optimization framework was applied by Cai et al. [23] to develop a renewable energy management system (REM) under uncertainty for community-scale renewable energy production facilities and supply chains. Pienaar and Brent [24] proposed and simulated a Biodiesel Production System Optimization Model (BPDOM) to predict the cost of producing biodiesel on a small-scale and optimize on-farm production process to maximize profits in South Africa. To deal with the challenge of supplying electricity in remote areas in India, Akella et al. [25] designed and applied an integrated renewable energy system (IRES) to optimize the potential resources and demands for meeting the energy needs in the Uttaranchal state in India. Using system dynamics modeling, Demczuk and Padula [26] evaluated the role of sugarcane yield, gasoline prices, and sales taxes rates on the feasibility of ethanol supply chain in the Brazilian southern region. To support the decision-making and the planning process of the Vietnamese power system expansion, Viet et al. [27] and Duong et al. [28] used linear power flow equations to propose a techno-economic model to optimize investments, operation costs, and locations to integrate renewable energy alternatives into the future Vietnamese power production and grid system. Ramakumar et al. [29] employed a linear programming approach to design and minimize the annual costs of integrated renewable energy systems for developing countries.

Given the issues presented above, the present study seeks to answer the following question: how does one develop and implement a cooperative "multi-countries" model of production and use of biodiesel in the SSA region, considering the challenges related to the structuring of the process of investment decision-making, the technological alternatives, the availability of agricultural land, the alternatives of raw material, the agricultural productivity, and the limitations of financial and human resources in SSA? To answer this question, the study proposes to develop a model for the optimization and simulation of biofuel production with the application of operational research and mathematical modeling tools that support the regional planning and decision-making process, satisfying the conditions and restrictions for cooperative production of biofuels in the countries of that region. In this context, this article aims to develop mathematical modeling that allows integrating and optimizing the available resources (land, capital, labor, and oilseed supply), to support the decision-making processes of the productive base (agricultural and industrial), which makes the cooperative productive configuration "multi-countries" viable, minimizing the costs of biodiesel production in the sub-Saharan region.

Mathematical programming, depending on the optimization problem, can be linear and non-linear. The first is used when the decision variables (objective function and constraints) are linear. Although its application, to a large extent, reflects only approximations to real facts, the linear programming modeling was employed preliminarily in this study assuming that the decision variables are linear and all conditions of equality and inequality restrictions are also linear. The methodological approach used was exploratory research, through the analysis of secondary socio-economic data from SSA 
countries to be covered by the modeling. The data were explored to scale and simulate the demand for biodiesel in each country analyzed, the cultivable raw materials, the costs of agricultural production of oilseeds and industrial processing, the extensions of arable land available for the farming of oilseeds and sugar-cane, as well as the installed capacity of the agribusiness necessary to supply the regional demand for biofuels (biodiesel and ethanol).

Biodiesel can be produced from several feedstocks, such as vegetable seeds, animal fat, synthetics, or a combination of these). However, there is still a predominance of raw materials of vegetable origin in the world, due to the maturation inherent in the technology of production of first-generation biodiesel, which occurs through the process of transesterification of vegetable oil. This process, however, may include inputs from ethyl (anhydrous ethanol) or methyl (methanol) groups, in the proportion of $10 \%$ to $13 \%$ per liter of biodiesel. However, in this article, it is assumed that the use of the ethylic route has a less aggressive environmental impact than that of methanol and its availability in the investigated region. It is also possible to observe that the need to expand the production of this input to meet the demand for biodiesel can create "green jobs", alleviating the socioeconomic vulnerability present in sub-Saharan Africa. Biodiesel plants have at least two strategic options to obtain anhydrous ethanol: (i) acquisition at market price, or (ii) internal production through organizational verticalization, creating an ethanol processing unit integrated with the biodiesel plant. In this article, however, it is based on the premise that the acquisition of anhydrous ethanol on the market would be more attractive for the biodiesel plant, which can direct its efforts in the optimization of agro-industrial biodiesel processing. In this approach, the critical points observed were the possession of arable land for the cultivation of oilseeds and sugar-cane in sub-Saharan Africa, considering that the land ownership system in this region establishes small hectares per family. Another critical issue concerns the need to avoid competition for land use for food production versus biofuels. Thus, only non-edible oilseeds will be evaluated as alternatives for the production of biodiesel. In this sense, the use of regional planning modeling allows verifying the productive and economic feasibility of using agricultural land in an optimized way, indicating oilseeds with higher oil productivity and lower production cost.

The built model was initially used in South Africa, where it was found that optimization allows minimizing the costs of biodiesel production in sub-Saharan African countries. It also made it possible to verify that anhydrous ethanol by-products (sugarcane bagasse and vinasse) have great potential to generate secondary energy, while glycerin from biodiesel processing can be marketed to the health and cosmetics industries, contributing to the economic feasibility of the biodiesel production chain. It is worth highlighting the originality and the added value of this paper. This study provides academics, policymakers, and managers with policy and strategy implications. On the one hand, from a "multi-countries" perspective, the decision-support model proposed in this study considers the main oilseeds with potential for biodiesel production in SSA and explores some relevant variables and constraints considered in the evaluation of the feasibility of investment on biodiesel production. The cooperative production of biodiesel proposed in this study will allow the minimization of biofuel production costs in the sub-Saharan region and may boost cooperation between SSA countries and make production and the consumption of biofuels in that region feasible. On the other hand, the literature on modeling the diversification of the energy matrix in SSA is still in its infancy, where the models of optimization of biofuel production used in most scientific works consider only a single country involved in the production and consumption of biofuel. Thus, this study adds the perspective of modeling "multi-countries" cooperative production as a contribution to academic studies and the policymaking process of biofuel production systems.

The article is structured in four sections. In the introductory section, the context and objectives of the research were presented. The second section presents the materials and methods adopted to achieve the objective of this work. This section presents the optimization model equations built to minimize the biodiesel production costs in SSA and the procedures for data collection and analysis. The third section presents and discusses the research results, in which the main findings were discussed, based on the application of the research data in the optimization model. The fourth and final section 
presents the conclusions and implications for making investment decisions in the implementation of the cooperative biodiesel production base in sub-Saharan Africa.

\section{Materials and Methods}

To achieve the proposed objective, a quantitative research method based on an exploratory analysis of the production and use of biodiesel in sub-Saharan Africa was adopted, developing a model for optimizing the production of this biofuel using mathematical programming. Mathematical programming, depending on the optimization problem, can be linear or non-linear. The first is used when the decision variables are linear. Although its application largely reflects only approximations to real facts, the linear programming modeling was employed preliminarily in this article assuming that the decision variables are linear and all conditions of equality and inequality restrictions are also linear $[30,31]$. The differential of this model consists of simplifying the formulation of the problem and precision in the results, using the simplex method [32]. Its working principle consists of starting the modeling with a certain solution for which all parameters are known and which satisfies the restrictions and the conditions of non-negativity $\left(x_{j} \geq 0, j=1,2,3, \ldots, \mathrm{n}\right)$. In this context, the main oilseeds with potential for biodiesel production in sub-Saharan Africa (palm oil, jatropha, and sunflower) were selected [15]. As such, these oilseeds do not have direct competition with food in sub-Saharan Africa. Thus, the decision variables were defined, namely, (1) area to be cultivated with palm, jatropha, and sunflower [33,34]; (2) oil from oilseed yield-liters per hectare (L/ha); and (3) production cost per hectare of oilseed. In this sense, the model implemented focused on minimizing the total costs of cultivating the selected oilseeds, considering the following four restriction classes (in addition to non-negativity): area to be planted, demand for biodiesel, inputs (anhydrous ethanol), and by-products (glycerin). The equations and inequalities (Equations (1) to (7)) formally present the proposed model.

$$
\operatorname{Min} C T(x)=C_{i} x_{1}+C_{i} x_{2}+C_{i} x_{3}
$$

Subject to,

$$
\begin{gathered}
x_{1}+x_{2}+x_{3} \geq 0 \\
x_{1}+x_{2}+x_{3} \leq \text { arable land for oilseeds in the country } \\
R_{r} x_{1}+R_{r} x_{2}+R_{r} x_{3}=\text { total biodiesel demand in the country } \\
0.13 R_{r} x_{1}+0.13 R_{r} x_{2}+0.13 R_{r} x_{3} \leq \text { anhydrous ethanol available in the country } \\
0.10 R_{r} x_{1}+0.10 R_{r} x_{2}+0.10 R_{r} x_{3} \leq \text { maximum glycerin generated } \\
X_{j} \geq 0, \text { for } j=1,2,3 \ldots
\end{gathered}
$$

where,

$\mathrm{CT}=$ total cost of oilseed production in the country;

$\mathrm{Ci}=$ production cost per hectare of oilseed area $\mathrm{x}_{\mathrm{i}}$ :

$$
\begin{gathered}
\mathrm{x}_{1}=\text { hectares of oilseed } \mathrm{x}_{1} ; \\
\mathrm{x}_{2}=\text { hectares of oilseed } \mathrm{x}_{2} ; \\
\mathrm{x}_{3}=\text { hectares of oilseed } \mathrm{x}_{3} ; \\
\mathrm{x}_{1}+\mathrm{x}_{2}+\mathrm{x}_{3}=\text { total land area }(\text { ha }) \text { cultivated with oilseeds in the country; } \\
\mathrm{R}_{\mathrm{r}} \mathrm{x}_{1}=\text { oil from oilseed yield } \mathrm{x}_{1}\left(\frac{\mathrm{L}}{\mathrm{ha}}\right) \text { ha } \mathrm{x}_{1} \text { (planted area); } \\
\mathrm{R}_{\mathrm{r} \mathrm{x}_{2}=} \text { oil from oilseed yield } \mathrm{x}_{2}\left(\frac{\mathrm{L}}{\mathrm{ha}}\right) \text { ha } \mathrm{x}_{2}(\text { planted area }) ;
\end{gathered}
$$




$$
\mathrm{R}_{\mathrm{r}} \mathrm{x}_{3}=\text { oil from oilseed yield } \mathrm{x}_{3}\left(\frac{\mathrm{L}}{\mathrm{ha}}\right) \text { ha } \mathrm{x}_{3} \text { (planted area); }
$$

$\mathrm{L}=$ liters;

ha $=$ hectares (planted area).

Given the above, it can be seen that the objective function and all the conditions of restrictions of this model are linear. This implies that every local optimum is also a global optimum and the optimal solution can only occur at a border point of a set of viable solutions, being considered a linear programming problem [32].

\subsection{Data Processing and Analysis}

Data processing and analysis were performed with the application of computational algorithms and Linear, Interactive, and Discrete Optimizer software (LINDO) to achieve greater reliability in the results [35]. These tools allowed running the built optimization model. In the context of validation of the built optimization model, it was initially tested with secondary data from South Africa [13,36], because of the results needed for comparative analysis. South Africa is a country that has peculiar characteristics in the sub-Saharan region, such as the availability of open-access statistical databases and a better-structured fuel production base in that region. When identifying the optimum value that minimizes the total cost of biodiesel production and the values of the restrictions, a data envelopment analysis was performed, allowing comparing the efficiency of the optimized variable with the analyzed variables, establishing an indicator of evaluation of the relationship between them. Then, a simulation of the cooperative production of a group of sub-Saharan African countries that share territorial borders (South Africa, Botswana, Malawi, Mozambique, Namibia, Zambia, and Zimbabwe) was carried out to scale and optimize the demands, production, costs, and job creation for the production of biodiesel in a cooperative manner between these countries. By-products from biodiesel inputs (anhydrous ethanol vinasse from sugarcane bagasse) have high calorific value for the production of electrical energy. In this context, the following indicators were used to analyze the potential of electric energy from vinasse (Equation (8)) (Gehring, C. G. Análise da geração de energia elétrica a partir do biogás produzido na fermentação anaeróbica de vinhaça. Monografia - Escola da Engenharia de São Carlos, Universidade de São Paulo, 2014.):

$$
\mathrm{E}=\mathrm{Q}_{\text {Biogas }} \mathrm{PCI}_{\text {Biogas }} \eta_{\text {Generator } \frac{4.184}{3600}}
$$

where,

$\mathrm{E}=$ electricity estimated for one crop year $(\mathrm{kWh} /$ day);

$\mathrm{Q}_{\text {Biogas }}=$ biogas flow factor, $11.5 \mathrm{~m}^{3}$ by $\mathrm{m}^{3}$ de vinasse $\left(\mathrm{m}^{3} /\right.$ day);

$\mathrm{PCI}_{\text {Biogas }}=$ lower calorific value of biogas $\left(\mathrm{kcal} / \mathrm{m}^{3}\right)$;

$\eta_{\text {Generator }}=$ generator motor efficiency $(\%)$;

4.184 = conversion factor from kcal to kJ;

$3600=$ conversion factor from seconds to hour.

The vinasse energy generation process takes place through an anaerobic digester. These indicators made it possible to project the potential for electricity cogeneration (MWh/year) in the biofuel chain in the cooperative countries of sub-Saharan Africa.

\subsection{Data Collection}

The data were collected from secondary sources of the Food and Agriculture Organization of the United Nations (FAO) Aquastat [36], the World Bank, specialized websites of the governments of sub-Saharan African countries, and studies on biofuel production agro-industries in the region, among others $[13,35,36]$.

In this approach, the critical points observed were the possession of arable land for the cultivation of oilseeds and sugarcane in sub-Saharan Africa, considering that the land ownership system in this 
region establishes small hectares per family. Another issue is related to the limitation in the availability of water for irrigation of unproductive land, to transform them into productive agricultural areas.

\subsection{Research Limits}

Few data are available on the socio-economic reality in sub-Saharan countries. Although there is a considerable number of biodiesel production initiatives in the sub-Saharan region, information about its production and economic/performance variables is scarce and incomplete. Therefore, some simplifications and reductions were necessarily employed in the creation of the scenarios, in the realization of the impact predictions of the biodiesel production and consumption alternatives. Despite these limitations, this study has theoretical implications (optimization modeling for "multi-countries" cooperation for production and consumption) and political implications (preliminary production scenarios) for the design and implementation of a "multi-countries" cooperative program for the production and consumption of biodiesel in the sub-Saharan region.

\section{Results and Discussions}

As stated in the Materials and Methods section, the modeling was performed and tested initially in South Africa, although the coefficients of some restrictions are from Brazil, the United States of America (USA), and Europe, since these countries have structured biodiesel and ethanol chains and have the necessary data to be inserted in the optimization model. Then, simulations of demand and production of biodiesel were carried out for a group of seven countries in the SSA region, to optimize and provide elements of viability to develop a "multi-countries" cooperation program for the production and use of biodiesel in that region. The results of the data envelopment analysis are also discussed in this section.

\subsection{Production of Biodiesel in South Africa}

The annual demand for biodiesel in South Africa was estimated from fossil diesel consumption in $2018\left(2,818,960 \mathrm{~m}^{3}\right)$, based on the raw data from the South African Statistical Information Agency [35]. Comparing the $156,824.78 \mathrm{~m}^{3}$ of biodiesel produced in South Africa in 2016 (the last survey carried out by the South African statistical agency) with the projected demand, it appears that the effective production in 2016 would represent only 52\% of the projected demand if the mandatory blend of B10 $\left(281,896 \mathrm{~m}^{3}\right)$ is used, as shown in Figure 1.

Figure 1 allows us to verify the demand for biodiesel from the variation in the percentage of the mandatory blend with fossil diesel and the demand for anhydrous ethanol as a reagent in the process of transesterification of vegetable oil to biodiesel. As for the production of the anhydrous ethanol reagent, the by-products generated in the production process (sugarcane bagasse and vinasse) can generate electric energy through cogeneration, while glycerin, which originates in the transesterification process, can be commercialized for soap production, contributing to the economic viability of the biodiesel plant. To optimize the production costs of biodiesel, a survey of the agricultural production data of the main oil crops (palm oil, jatropha, sunflower, castor bean, soybean, and cottonseed) grown in South Africa was carried out. The data involve the costs of agricultural production of oilseeds in dollars per hectare (US\$/ha), productivity (kg/ha), and the yield of vegetable oil (L/ha), according to Table 1.

Three oilseed crops were selected for analysis (palm oil, jatropha, and sunflower). The other crops were excluded from the model due to the high cost of agricultural production and agro-industrial processing or the possibility of generating strong direct competition with food production. 


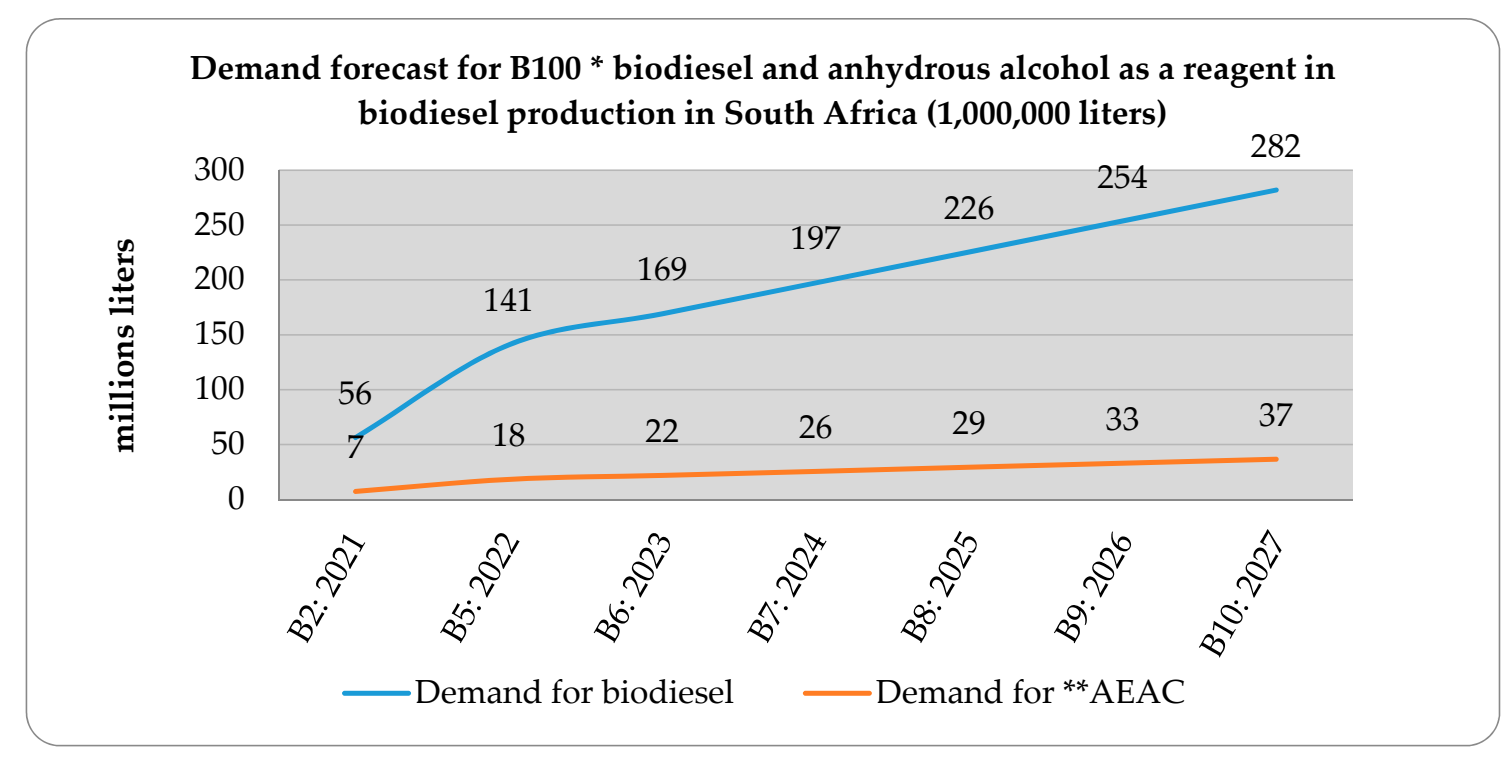

Figure 1. Demand projection for biodiesel in South Africa (2021-2027). * B100 = pure biodiesel $(100 \%)$. B2 to B10 $=\%$ blend of biodiesel with fossil diesel. B2 $=2 \%$ biodiesel; B10 $=10 \%$ biodiesel. ** AEAC $=$ fuel anhydrous ethyl alcohol (anhydrous ethanol). Source: Authors, based on data from International Energy Statistics [35].

Table 1. Costs and productivity of oilseeds used in the production of biodiesel that are grown in South Africa (2018).

\begin{tabular}{cccc}
\hline Biomass & Production Cost (US\$/ha) & Productivity (kg/ha) & Oil Yield (L/ha) \\
\hline Palm oil & 508.73 & 22,000 & 5950 \\
Jatropha & 618.62 & 2500 & 1892 \\
Sunflower & 519.55 & 1526 & 952 \\
Peanut & 989.61 & 3702 & 1059 \\
Castor bean & 349.54 & 615 & 1413 \\
Soybeans & 872.91 & 3359 & 446 \\
Cotton seed & 1639.29 & 2498 & 325 \\
\hline
\end{tabular}

Source: Authors, from International Energy Statistics [13,35,37].

\subsection{Application of the Model in South Africa}

According to the data in Table 1, the objective function of the model (total cost of growing oilseeds) can be composed, in which the decision variables are the areas to be planted and harvested from the following oilseeds: palm oil $\left(\mathrm{x}_{1}\right)$, jatropha $\left(\mathrm{x}_{2}\right)$, and sunflower $\left(\mathrm{x}_{3}\right)$. Equation 9 presents the mathematical expression of the total cost:

$$
\operatorname{Min} C T(X)=508 x_{1}+618 x_{2}+519 x_{3}
$$

To identify and analyze the availability of agricultural land for oilseed production, a survey of data from 15 countries in sub-Saharan Africa [13] was carried out, as shown in Table 2.

It is possible to verify that some countries have a very small arable land area, which could cause conflicts of interest and competition in land use for the cultivation of oilseeds or food production.

In South Africa, the extent of agricultural land available is 12,087,000 ha (Table 2). Although only a small portion should be used for the cultivation of oilseeds, the first restriction of the optimization model was built based on the total extension to analyze the model's behavior (Equation (10)). In Equation (10), $x_{1}$ is the palm oil area, $x_{2}$ is the jatropha area, and $x_{3}$ is the sunflower area.

$$
\mathrm{x}_{1}+\mathrm{x}_{2}+\mathrm{x}_{3} \leq 12,087,000
$$


Oilseed productivity in sub-Saharan Africa varies according to the climate and soil fertility conditions in each country and the technologies used in seed processing. Sugarcane represents a predominant crop in ethanol production in the region, while jatropha represents the raw material most used in the production of biodiesel. Oil yield also varies across SSA countries, as illustrated in Table 3.

Table 2. Area of arable land (in 1000 ha) of selected countries, 2018.

\begin{tabular}{cccc}
\hline Country & $\begin{array}{c}\text { Arable Land Area } \\
(\mathbf{1 0 0 0} \text { ha) }\end{array}$ & $\begin{array}{c}\text { Permanent Area } \\
(\mathbf{1 0 0 0} \text { ha) }\end{array}$ & $\begin{array}{c}\text { Total Available Area } \\
\mathbf{( 1 0 0 0 ~ h a )}\end{array}$ \\
\hline Angola & 4900 & 290 & 4610 \\
South Africa & 12,500 & 413 & 12,087 \\
Benin & 2700 & 500 & 2200 \\
Gambia & 440 & 5 & 435 \\
Guinea Bissau & 300 & 250 & 50 \\
Botswana & 399 & 2 & 397 \\
Mozambique & 5650 & 300 & 5350 \\
Ghana & 4700 & 2700 & 2000 \\
Namibia & 800 & 9 & 791 \\
Nigeria & 34,000 & 6500 & 27,500 \\
DRC & 7100 & 900 & 6200 \\
Senegal & 3200 & 68 & 3132 \\
Malawi & 3800 & 140 & 3660 \\
Tanzania & 13,500 & 2693 & 10,807 \\
Zambia & 3800 & 36 & 3764 \\
Zimbabwe & 4000 & 100 & 3900 \\
\hline
\end{tabular}

Source: Authors, based on FAO data-AQUASTAT [36]. * Democratic Republic of Congo (RDC).

Table 3. The average yield of oil liter/ha of oilseeds in sub-Saharan Africa (2016).

\begin{tabular}{ccc}
\hline Feedstock & Liters/Hectare(L/ha) & Countries that Grow Raw Materials \\
\hline Palm oil & 5950 & Angola, Ghana, Nigeria, DRC * and Tanzania; \\
Coconut & 2689 & Ghana, Mozambique, Nigeria, Senegal and Tanzania; \\
Avocado & 2638 & South Africa, Ghana, Nigeria, DRC * and Senegal; \\
Jatropha & 1892 & South Africa, Benin, Ghana, Malawi, Mozambique, Nigeria, \\
and Tanzania; \\
Castor bean & 1413 & South Africa, Angola, DRC* and Mozambique; \\
Peanut & 1059 & Angola, Gambia, Ghana, Malawi, Mozambique, DRC , Senegal, Zambia, \\
and Zimbabwe; \\
$\begin{array}{c}\text { Sunflower } \\
\text { Soybeans }\end{array}$ & 952 & Angola, Botswana, Ghana, Malawi, Nigeria and DRC; \\
Cottonseed & 446 & South Africa, Ghana, Malawi, DRC and Tanzania; \\
Cashew nut & 325 & South Africa, Angola, Ghana, Malawi, Mozambique, Tanzania, Zambia, \\
and Zimbabwe; \\
\end{tabular}

* The Democratic Republic of Congo. Source: Adapted from Sekoai and Yoro [13].

According to Table 3, palm oil has a higher oil yield per hectare among the oilseeds used in the production of biodiesel (coconut and avocado are not used in the production of biodiesel in SSA), followed by jatropha, castor, peanuts, and sunflower.

The forecast for biodiesel demand was established according to the percentage of the volume of diesel consumed in South Africa in $2018\left(2,818,960 \mathrm{~m}^{3}\right)$. Therefore, to meet the B2 demand, 56,379,206 L/year of biodiesel would be necessary, with a growing trend, as already evaluated. In this context, the configuration of the second model constraint is defined according to Equation (11).

$$
5950 x_{1}+1892 x_{2}+952 x_{3}=56,379,206
$$

Aiming to determine the production of biodiesel from the ethyl route, the technical coefficient established to guarantee the quality and efficiency in biodiesel processing was $0.13 \mathrm{~L}$ of anhydrous 
ethanol/L of biodiesel [33]. In this sense, the proportion of anhydrous ethanol should be multiplied by oilseed yield per hectare (ha) planted $(0.135950+0.131982+0.13952)$. According to International Energy Statistics [35], the volume of anhydrous ethanol available in South Africa corresponds to $189,029,018 \mathrm{~L}$ in 2018. It cannot be destined in its entirety as a reagent in the production of biodiesel, but it was added to test the built model. This allowed us to present the third constraint (Equation (12)). This restriction establishes that the demand for anhydrous ethanol to produce biodiesel cannot be greater than the volume available in the analyzed country.

$$
773.5 \mathrm{x}_{1}+245.96 \mathrm{x}_{2}+123.76 \mathrm{x}_{3} \leq 189,029,018
$$

Regarding the generation of glycerin (a by-product from biodiesel processing), Brazilian environmental standards ABNT NBR 15,341 and 15,771 were applied, which specifies the generation of up to $0.10 \mathrm{~L}$ glycerin/L biodiesel. This specification was used because it is not available in South Africa's data, but it meets international quality criteria [33]. Thus, this volume of glycerin was multiplied by the oil yield of oilseeds $(0.15950+0.121982+0.10952+0.10952)$. In this context, the glycerin generated cannot be greater than $10 \%$ of the total biodiesel demand (Equation (13)):

$$
595 \mathrm{x}_{1}+189.2 \mathrm{x}_{2}+95.2 \mathrm{x}_{3} \leq 5,637,921
$$

In this perspective, to optimize the production of biodiesel, mathematical modeling of linear programming was applied to the problem of minimizing the cost of producing vegetable oil for biodiesel, according to Equations (14) to (20):

$$
\operatorname{Min} C T(X)=508 x_{1}+618 x_{2}+519 x_{3}
$$

Subject to,

$$
\begin{gathered}
x_{1}+x_{2}+x_{3} \geq 0 \\
x_{1}+x_{2}+x_{3} \leq 12,087,000 \\
5950 x_{1}+1892 x_{2}+952 x_{3}=56,379,206 \\
773.5 x_{1}+245.96 x_{2}+123.76 x_{3} \leq 189,029,018 \\
595 x_{1}+189.2 x_{2}+95.2 x_{3} \leq 5,637,921 \\
x_{j} \geq 0, \text { for } j=1,2,3 \ldots
\end{gathered}
$$

This mathematical modeling (Equations (14) to (20)) was initially processed in Solver (Microsoft Excel $\left.{ }^{\circledR}\right)$, using the Simplex Method, which found the optimal solution for the production of oilseeds for biodiesel according to the annual demand for a $2 \%$ blend of biodiesel with fossil diesel (B2) in South Africa, in which all conditions of restrictions were satisfied, with the minimum cost of producing vegetal oil calculated being US $\$ 4,813,552 /$ year, from palm oil $\left(\mathrm{x}_{1}\right)$. The costs of jatropha oil $\left(\mathrm{x}_{2}\right)$ is US $\$ 18,515,616 /$ year and for sunflower $\left(x_{3}\right)$ US $\$ 30,736,139 /$ year.

Then, a sensitivity analysis was performed in LINDO software to check the limits of the decision variables. As shown in Figure 2, the optimization generated indicates that only palm oil should be used for the production of biodiesel, and this decision does not change even though the unit costs of jatropha and sunflower can be reduced by up to US $\$ 456$ and US $\$ 437$, respectively. 


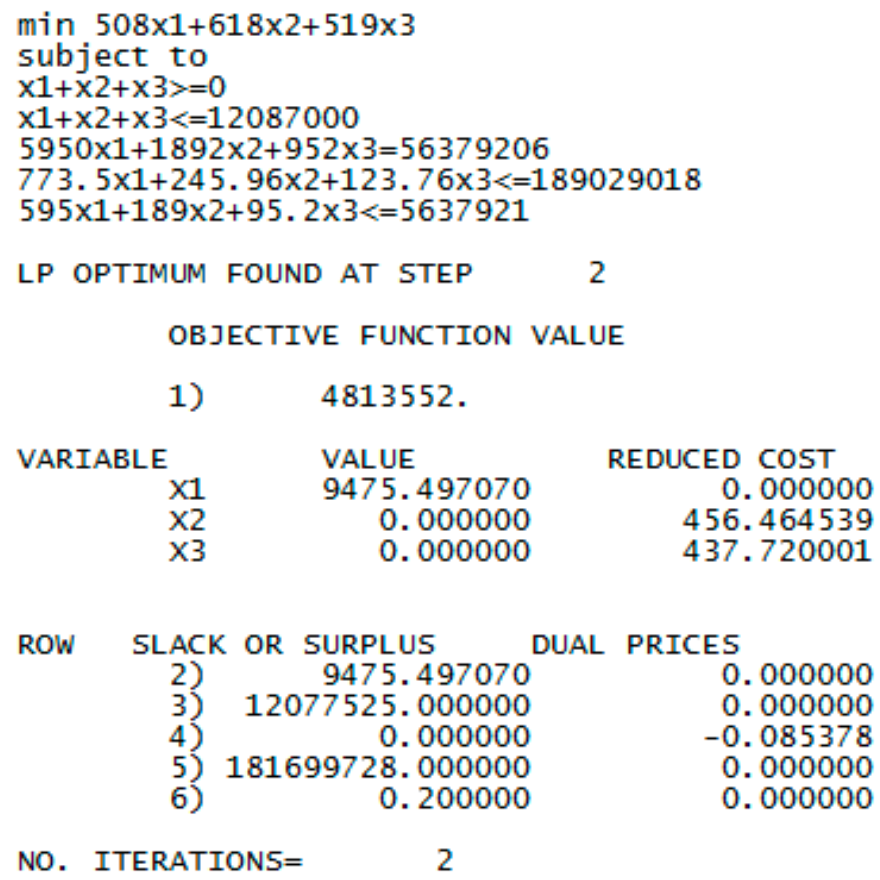

Figure 2. Results of the data analysis using LINDO software. Source: Authors, based on research data.

After identifying the oilseed that minimizes the cost of agricultural biodiesel production in South Africa (palm), an analysis of the costs of agro-industrial biodiesel production was carried out to replicate the optimization model built in sub-Saharan Africa.

According to these results, it was found that, to meet a demand for B2 in South Africa, palm oil $\left(\mathrm{x}_{1}\right)$ is the oilseed with the lowest cost of agricultural production (US\$4,813,552). Jatropha $\left(\mathrm{x}_{2}\right)$ occupies the second position with an agricultural production cost of US\$18,415,616 and sunflower $\left(x_{3}\right)$, occupies the third position with an agricultural production cost of US\$30,736,139. These costs were calculated by substituting the oilseed yield per planted hectare and the cost of agricultural production.

The modeling presented in the equations (Equations (14) - (20)) reveals that to meet the demand for biodiesel from the B2 mixture in South Africa with palm oil, due to its high oil productivity per hectare (5950 L/ha), it would be necessary a cultivation area of 9475 ha. While jatropha, in turn, has a lower oil productivity per hectare (1892 L/ha) and would require a greater extent of land cultivated 29,799 ha.

According to the estimates made, the jatropha would require an area of agricultural production approximately three (3) times larger than the area required by the palm. Sunflower, however, due to the lower oil productivity per hectare (952 L/ha), would require a cultivated area of 59,221.86 ha to meet the demand for B2 in South Africa. Alternative cost, land saving, and vegetable oil yield for biodiesel production in South Africa.

Considering palm oil as the best alternative raw material for biodiesel, the total cost of agricultural production and pre-processing of oilseeds is US $\$ 30,184,192$ (US $\$ 4,813,552+$ US $\$ 25,370,640$, respectively). Thus, the total production cost of 56,379,206 L of biodiesel to supply B2's demand in South Africa is equal to US $\$ 45,970,368$ (US $\$ 30,184,192$ + US $\$ 15,786,176$ ), which corresponds to US $\$ 0.82 / \mathrm{L}$ (US $\$ 45,970,368 \div$ $56,379,206 \mathrm{~L}$ of biodiesel).

To assess the specific costs for the industrial biodiesel production process with the available and representative data of the reality in sub-Saharan Africa, the transesterification of jatropha oil observed in Tanzania, Mozambique, and Mali was used as a basis; the operating costs in these countries reflect the reality of the biodiesel agribusiness in Africa. Table 4 shows the breakdown of the production costs. 
Table 4. The average cost of the transesterification of oilseeds to biodiesel in Africa in 2012.

\begin{tabular}{cc}
\hline Description & US $\$ \mathbf{L}$ \\
\hline Pre-processing of oilseeds & \\
Transport/logistics of seed from agriculture to the refinery & 0.25 \\
Conversion of seeds to biodiesel & 0.2 \\
Subtotal pre-processing and seed logistics for biodiesel & 0.45 \\
Transesterification & 0.02 \\
Depreciation of equipment per liter of biodiesel & 0.001 \\
Cost of electricity consumption & 0.19 \\
Water needed for production & 0.01 \\
Cost of methanol for the production of biodiesel (200 mL per L of biodiesel) & 0.01 \\
Cost of caustic soda in production (4 g per L) & 0.05 \\
Labor (work) & 0.28 \\
Subtotal transesterification & 0.73 \\
\hline
\end{tabular}

Source: Adapted from Romijn et al. [14]; Eijck, Smeets and Faaij [17].

Table 4 made it possible to estimate the total annual costs (US\$25,370,640) of the pre-processing of oilseeds for biodiesel according to the annual demand for B2 in South Africa and its corresponding unit cost (US\$0.45/L). In turn, the estimated cost for industrial processing (transesterification) would be US $\$ 15,786$. Considering the unit cost of US $\$ 0.28 / \mathrm{L}$, it adds the total cost of US\$ $0.82 / \mathrm{L}$ of biodiesel. In this sense, agricultural production accounts for $66 \%$ of total costs and agro-industrial processing (transesterification) represents $34 \%$ of total costs [15]. It is worth noting that this cost composition is different from that observed in Brazil by Dos Santos et al. [38-40], who identified that the cost of agricultural production of oilseeds corresponds to $80 \%$ to $90 \%$ of the total production costs of biodiesel.

Considering the average sale price of fossil diesel at resale stations in South Africa (US\$0.90/L) in 2016, at a cost of biodiesel production of US $\$ 0.82 / \mathrm{L}$, biodiesel will have limitations in its competitiveness in the liquid fuels market [41]. This situation reveals that, as in Brazil, the biodiesel production and consumption program will need to have subsidies and tax incentives for its market viability $[38,41]$.

Given this, the potential for "green jobs" in the biodiesel agribusiness was also projected based on the van Gerpen model [42-44] on the production of liquid biofuels, which allowed us to verify that 846 direct jobs can be generated in the biodiesel agribusiness and 5635 agriculture jobs to meet mandatory biodiesel blending of up to B10 in South Africa.

Although jatropha's agricultural production ranked second in the order of minimum production costs, it is an oilseed widely used in biodiesel production initiatives in several countries in the sub-Saharan region and has a great capacity to generate jobs in its agricultural production $[10,14,15]$. Thus, in this study, we also explored the alternative of producing biodiesel from jatropha oil so that we can make a comparative analysis and support the decision-maker in the choice between producing the oilseed that minimizes costs (palm oil) or the one that generates the most jobs (jatropha). The results of simulations of biodiesel production from jatropha are summarized in Table 5.

From the results of Table 5, the total cost of producing biodiesel from jatropha can be determined, which is US $\$ 1.05 / \mathrm{L}$. This figure is $28 \%$ higher than the cost of producing biodiesel from palm oil (US\$0.82/L). This result implies that biodiesel produced from jatropha will have greater limitations for its competitiveness in the fuel market in South Africa than biodiesel produced from palm oil. On the other hand, the production of biodiesel from jatropha to meet the demand for the B10 blend has the potential to generate approximately five (5) times the number of jobs $(32,843)$ than from palm oil (6531). In this way, it is up to the decision-makers to define policies that best meet the country's social, economic, and energy needs. The decision will fall on producing at lower costs (palm oil) or choosing to generate a greater number of jobs (jatropha). If the choice falls on jatropha, it will be necessary to target greater volumes of subsidies and tax incentives to make biodiesel competitive in the fuel (diesel) market. 
Table 5. Costs, areas, and labor involved in the production of jatropha biodiesel in South Africa.

\begin{tabular}{|c|c|c|c|c|c|c|c|}
\hline BX & $\begin{array}{l}\text { Biodiesel } \\
\text { Demand } \\
\text { (L) }\end{array}$ & $\begin{array}{l}\text { Jatropha } \\
\text { Cultivation } \\
\text { Area (ha) }\end{array}$ & $\begin{array}{l}\text { Cost of Growing } \\
\text { Jatropha } \\
\text { (US\$608/ha) (a)* }\end{array}$ & $\begin{array}{l}\text { Oilseed Logistics Cost } \\
\text { and Transesterification } \\
\text { (US\$ } \$ .73 / \mathrm{L})(\mathrm{b}) * *\end{array}$ & $\begin{array}{l}\text { Total Cost } \\
\text { (US\$) } \\
(a+b)\end{array}$ & $\begin{array}{l}\text { Direct Labor in } \\
\text { the Agribusiness } \\
(0.0000108 / \mathrm{L}) * * *\end{array}$ & $\begin{array}{c}\text { Direct Labor } \\
\text { in Agriculture } \\
(0.2 / \mathrm{ha}) * * *\end{array}$ \\
\hline B2 & $56,379,200$ & 29,799 & $18,415,616$ & $41,156,816$ & $59,572,432$ & 609 & 5960 \\
\hline B5 & $140,948,000$ & 74,497 & $45,294,176$ & $102,892,040$ & $148,186,216$ & 1522 & 14,899 \\
\hline B6 & $169,137,600$ & 89,396 & $54,352,768$ & $123,470,448$ & $177,823,216$ & 1827 & 17,879 \\
\hline B7 & $197,327,200$ & 104,296 & $63,411,968$ & $144,048,856$ & $207,460,824$ & 2131 & 20,859 \\
\hline B8 & $225,516,800$ & 119,195 & $72,470,560$ & $164,627,264$ & $237,097,824$ & 2436 & 23,839 \\
\hline B9 & $253,706,400$ & 134,094 & $81,529,152$ & $185,205,672$ & $266,734,824$ & 2740 & 26,819 \\
\hline B10 & $281,896,000$ & 148,994 & $90,588,352$ & $205,784,080$ & $296,372,432$ & 3044 & 29,799 \\
\hline
\end{tabular}

Source: ${ }^{*}$ Table $1 ;{ }^{* *}$ Table $4 ;{ }^{* *}$ Calculated from Ceplac [39], ROMIJN et al. [14], FGV [45], MAPA [46], and Zambrano et al. [47].

\subsection{Exploring the Optimization Model to Project the Supply and Consumption of "Multi-Countries" Cooperative Biodiesel in Sub-Saharan Africa}

Bearing in mind that several SSA countries have very little demand for biodiesel [48], which would make the economic scale unfeasible to justify the installation of the biofuel agribusiness, there was an opportunity for cooperation between countries in this region for the production of biodiesel and reduce dependence on diesel oil imports.

In this context, the research proposes a cooperative action between seven countries in the sub-Saharan region that are geographically close: South Africa, Botswana, Malawi, Mozambique, Namibia, Zambia, and Zimbabwe. Thus, the demand for biodiesel for this group of SSA countries was simulated (Table 6).

Table 6. Simulation of the demand for biodiesel in a group of seven neighboring countries in sub-Saharan Africa (SSA) based on diesel consumption forecast for 2020.

\begin{tabular}{|c|c|c|c|c|c|c|c|c|}
\hline \multirow{2}{*}{ Country } & \multirow{2}{*}{$\begin{array}{l}\text { Diesel Consumption } \\
\qquad\left(\mathrm{m}^{3}\right)\end{array}$} & \multicolumn{7}{|c|}{ Biodiesel Demand BX $\left(\mathrm{m}^{3}\right)$} \\
\hline & & B2 & B5 & B6 & B7 & B8 & B9 & B10 \\
\hline South Africa & $11,087,073$ & 221,740 & 554,350 & 665,220 & 776,090 & 886,960 & 997,830 & $1,108,700$ \\
\hline Botswana & 542,000 & 10,840 & 27,100 & 32,520 & 37,940 & 43,360 & 48,780 & 54,200 \\
\hline Malawi & 121,000 & 2420 & 6050 & 7260 & 8470 & 9680 & 10,890 & 12,100 \\
\hline Mozambique & $1,256,000$ & 5120 & 62,800 & 75,360 & 87,920 & 100,480 & 113,040 & 125,600 \\
\hline Namibia & 522,000 & 10,440 & 26,100 & 31,320 & 36,540 & 41,760 & 46,980 & 52,200 \\
\hline Zambia & 474,000 & 9,480 & 23,700 & 28,440 & 33,180 & 37,920 & 42,660 & 47,400 \\
\hline Zimbabwe & 588,000 & 11,760 & 29,400 & 35,280 & 41,160 & 47,040 & 52,920 & 58,800 \\
\hline Total & $14,590,000$ & 271.800 & 729,500 & 875,400 & $1,021,300$ & $1,167,200$ & $1,313,100$ & $1,459,000$ \\
\hline
\end{tabular}

Source: From Transnet SOC Ltd. [43] and UNDATA [48].

From Table 6, there was a need for initial installations of agro-industries with the capacity to produce $\left(271,800 \mathrm{~m}^{3} /\right.$ year) of biodiesel to meet the demand for B2 blending.

As for the forecast of diesel demand in the coming decades in these countries, the estimates showed significant growth in consumption [48]. However, it will be a slow growth, due to the development of a new energy mix in the future (biogas, wind, solar, nuclear energy, and natural gas) for electricity generation and industrial applications (Table 7).

Table 7. Projection of regional demand for biodiesel $\left(\mathrm{m}^{3}\right)$ from seven SSA countries based on the projection of diesel consumption (2020 to 2046).

\begin{tabular}{ccccccccc}
\hline \multirow{2}{*}{ Year } & $\begin{array}{c}\text { Demand for Liquid } \\
\text { Diesel } \mathbf{( m}^{\mathbf{3}} \mathbf{)}\end{array}$ & \multicolumn{8}{c}{ Projection of Biodiesel Demand in the Group of Selected Countries $\mathbf{( m}^{\mathbf{3}}$ ) } \\
\cline { 3 - 8 } & & $\mathbf{B 2}$ & B5 & B6 & B7 & B8 & B9 & B10 \\
\hline 2020 & $17,009,000$ & 340,180 & 850,450 & $1,020,540$ & $1,190,630$ & $1,360,720$ & $1,530,810$ & $1,700,900$ \\
2021 & $17,066,000$ & 341,320 & 853,300 & $1,023,960$ & $1,194,620$ & $1,365,280$ & $1,535,940$ & $1,706,600$ \\
2026 & $20,064,000$ & 401,280 & $1,003,200$ & $1,203,840$ & $1,404,480$ & $1,605,120$ & $1,805,760$ & $2,006,400$ \\
2031 & $22,005,000$ & 440,100 & $1,100,250$ & $1,320,300$ & $1,540,350$ & $1,760,400$ & $1,980,450$ & $2,200,500$ \\
2046 & $27,082,000$ & 541,640 & $1,354,100$ & $1,624,920$ & $1,895,740$ & $2,166,560$ & $2,437,380$ & $2,708,200$ \\
\hline \multicolumn{8}{c}{ Source: From Transnet SOC Ltd. $[43]}$.
\end{tabular}


According to Table 7, the projection of the demand for biodiesel shows slow growth, but if the mandatory blend is increased to $10 \%$ or more, there may be a significant demand for biodiesel. The estimates also identified that the expansion of the productive scale to reach the demand of these countries can only occur in the countries with a large extension of available land with agricultural aptitudes, such as Mozambique, Tanzania, and Zambia, as shown in Table 2. These countries already have initiatives for the production and consumption of the first-generation biofuel, but the scale of production is still very small.

The results of the projections also reveal that, as in South Africa, palm oil represents the most attractive oilseed, with an agricultural production cost of US $\$ 29,043,939 /$ year and the need for 57,173 ha of cultivated land to meet the demand for biodiesel from the B2 mixture in the seven countries that will be part of the cooperative production and consumption of biodiesel. However, if the palm is removed from the model, the recommended oilseed becomes jatropha, whose agricultural production cost is US $\$ 111,115,877 /$ year and the need for 179,799 ha of land for cultivation. Sunflower, however, has a higher production cost than previous oilseeds (US\$185,455,273/year) and will need 357,332 ha of land. Table 8 presents the results of the simulation of the optimization of production costs, the need for an area for agricultural cultivation, and the generation of jobs to meet the regional demand for biodiesel with palm oil.

Table 8. Results of the projection of production cost optimization, cultivation area, and job generation to meet the regional demand for palm oil biodiesel in the seven countries based on estimates for 2020.

\begin{tabular}{|c|c|c|c|c|c|c|c|}
\hline $\mathbf{B X}$ & $\begin{array}{c}\text { Biodiesel } \\
\text { Demand (L) }\end{array}$ & $\begin{array}{l}\text { Palm Oil } \\
\text { Cultivation } \\
\text { Area (ha) }\end{array}$ & $\begin{array}{c}\text { Palm Oil } \\
\text { Cultivation Cost } \\
\text { (US\$508/ha) (a) }{ }^{*}\end{array}$ & $\begin{array}{c}\text { Logistics } \\
\text { and Transesterification } \\
\text { Cost }(\mathrm{US} \$ 0.73 / \mathrm{L})(\mathrm{b}) * *\end{array}$ & $\begin{array}{l}\text { Total Cost } \\
\text { (US\$) } \\
(a+b)\end{array}$ & $\begin{array}{l}\text { Direct Labor in } \\
\text { the Agro-industrial } \\
(0.000003 / \mathrm{L})^{* * *}\end{array}$ & $\begin{array}{c}\text { Direct Labor } \\
\text { in Agriculture } \\
(0.12 / \mathrm{ha}) * * *\end{array}$ \\
\hline B2 & $340,180,000$ & 57,173 & $29,043,939$ & $248,331,400$ & $277,375,339$ & 1021 & 6861 \\
\hline B6 & $1,020,540,000$ & 171,519 & $87,131,818$ & $744,994,200$ & $832,126,018$ & 3062 & 20,582 \\
\hline B7 & $1,190,630,000$ & 200,106 & $101,653,788$ & $869,159,900$ & $970,813,688$ & 3572 & 24,013 \\
\hline B8 & $1,360,720,000$ & 228,692 & $116,175,758$ & $993,325,600$ & $1,109,501,358$ & 4082 & 27,443 \\
\hline B9 & $1,530,810,000$ & 257,279 & $130,697,728$ & $1,117,491,300$ & $1,248,189,028$ & 4592 & 30,873 \\
\hline
\end{tabular}

Source: Tables 6 and 7; * Table 1; ** Table 3; *** Calculated from van Gerpen [42], Ceplac [39], ROMIJN et al. [14], FGV [45], MAPA [46], and Zambrano et al. [47].

As shown in Table 8, to meet the regional demand for B2 biodiesel, for example, it would be necessary to plant 57,173 ha of land with palm oil with total production costs of US $\$ 277,375,339 /$ year (US\$0.82/L). This biodiesel production would generate a total of 7882 jobs (1021 jobs in the processing industry plus 6861 in agriculture). Since it is a cooperative production and consumption initiative between several countries (multi-countries), the above values must be added to the logistics and transport costs for the distribution of biodiesel among the partner countries in the initiative. The logistics of the biodiesel industry in these countries can be structured through distribution centers, taking into account the location of the sources of raw materials (agricultural production of oilseeds) and the major centers of consumption of biodiesel.

Just as was done for South Africa, a comparative estimate of production costs, the need for land to grow oilseeds, and the generation of jobs to meet the regional "multi-countries" demand for biodiesel was carried out between palm and jatropha (Table 9). 
Table 9. Compared estimates of production cost, cultivated area, and job creation between palm oil and jatropha biodiesel in the seven cooperative countries based on estimates for 2020.

\begin{tabular}{|c|c|c|c|c|c|c|c|}
\hline \multirow[t]{2}{*}{ BX } & \multirow{2}{*}{$\begin{array}{c}\text { Biodiesel } \\
\text { Demand }\left(\mathrm{m}^{3}\right)\end{array}$} & \multicolumn{2}{|c|}{ Growing Area (ha) } & \multicolumn{2}{|c|}{$\begin{array}{c}\text { Direct Labor } \\
\text { (Agribusiness + } \\
\text { Agriculture) }\end{array}$} & \multicolumn{2}{|c|}{$\begin{array}{l}\text { The Total Cost of Biodiesel } \\
\text { Production (in US Dollars) }\end{array}$} \\
\hline & & Palm Oil & Jatropha & Palm Oil & Jatropha & $\begin{array}{c}\text { Palm Oil } \\
\text { (US\$0.82/L) }\end{array}$ & $\begin{array}{l}\text { Jatropha } \\
\text { (US\$1.05/L) }\end{array}$ \\
\hline B2 & 340,180 & 57,173 & 179,799 & 7882 & 39,634 & $277,375,339$ & $359,447,277$ \\
\hline B5 & 850,450 & 142,933 & 449,498 & 19,703 & 99,085 & $693,438,349$ & $894,123,215$ \\
\hline B6 & $1,020,540$ & 171,519 & 539,397 & 23,644 & 118,901 & $832,126,018$ & $1,072,947,858$ \\
\hline B7 & $1,190,630$ & 200,106 & 629,297 & 27,585 & 138,718 & $970,813,688$ & $1,251,772,500$ \\
\hline B8 & $1,360,720$ & 228,692 & 719,197 & 31,525 & 158,535 & $1,109,501,358$ & $1,430,597,143$ \\
\hline B9 & $1,530,810$ & 257,279 & 809,096 & 35,465 & 178,352 & $1,248,189,028$ & $1,609,421,786$ \\
\hline B10 & $1,700,900$ & 285,866 & 898,996 & 39,407 & 198,169 & $1,386,876,697$ & $1,788,246,429$ \\
\hline
\end{tabular}

Source: Authors, calculated from Romijn et al. [14], Ceplac [39], van Gerpen [42], FGV [45], MAPA [46], and Zambrano et al. [47].

According to the results presented in Table 9, to meet the demand for biodiesel established by the B2 blend, for example, the area needed for the agricultural production of jatropha would be approximately 3.1 times the area destined for palm oil and the production cost would be 1.3 times the cost of palm oil biodiesel. On the other hand, the capacity to generate jobs in the production of biodiesel from jatropha would be 5.0 times the capacity of palm oil. So, there seems to be a trade-off in the criteria and decision process on which oilseed to use as raw material for the production of biodiesel: lower costs and smaller agricultural areas or greater generation of jobs? It should be noted that the palm has a life cycle of 25 to 30 years, which could guarantee the raw material for biodiesel agribusiness for a longer time horizon [46].

In this perspective, it will be necessary to build public and private strategies and policies to guide the investment decision-making process, since both land resources (food production) and financial resources are notably scarce in the sub-Saharan region [49]. The need to generate jobs and income is also part of the objectives, efforts, and investment for the development of sub-Saharan Africa. Thus, as in the South African case, the decision will fall on (a) producing at lower costs (palm oil) or (b) choosing to generate a greater number of jobs (jatropha).

It was also possible to estimate the values (US\$) that would be saved with the reduction in conventional diesel imports in the seven countries mentioned in Table 6. To obtain approximate values with the reality of the sub-Saharan region, the calculations are based on the sales prices of diesel at the pump in South Africa in 2016, worth US\$0.90/L (Table 10).

Table 10. Estimated reduction in spending on diesel imports in the set of seven countries considered (2019-2046).

\begin{tabular}{cccccccc}
\hline \multirow{2}{*}{ Year } & \multicolumn{6}{c}{ Projected Reduction of Expenses with Diesel Imports (US\$0.90/L), 1000US\$ } \\
\cline { 2 - 8 } & B2 & B5 & B6 & B7 & B8 & B9 & B10 \\
\hline 2020 & 306,162 & 765,405 & 918,486 & $1,071,567$ & $1,224,648$ & $1,377,729$ & $1,530,810$ \\
2021 & 307,188 & 767,970 & 921,564 & $1,075,158$ & $1,228,752$ & $1,382,346$ & $1,535,940$ \\
2026 & 361,152 & 902,880 & $1,083,456$ & $1,264,032$ & $1,444,608$ & $1,625,184$ & $1,805,760$ \\
2031 & 396,090 & 990,225 & $1,188,270$ & $1,386,315$ & $1,584,360$ & $1,782,405$ & $1,980,450$ \\
2046 & 487,476 & $1,218,690$ & $1,462,428$ & $1,706,166$ & $1,949,904$ & $2,193,642$ & $2,437,380$ \\
\hline \multicolumn{7}{c}{ Source: Authors, }
\end{tabular}

The values presented in Table 10 are substantial and may contribute effectively to reducing energy dependence on oil and foreign currency spending with imports. For example, the volume of biodiesel to supply the B10 demand in 2031 has the potential to reduce US\$1.98 billion/year of the expenses on oil imports. 
The by-products generated in the production of biodiesel and anhydrous ethanol (used as a reagent for the transesterification of vegetable oil that generates biodiesel) also have a high calorific value for the generation of electric energy and may contribute as a renewable energy source for the different countries participating in the cooperative "multi-countries" initiative for the production of biodiesel. Thus, an estimate was made of the energy power generated with the biogas from vinasse and sugarcane bagasse based on the Gehring model [37] and data from Agência Embrapa de Inovação Tecnológica (Embrapa Technological Information Agency) [50].

In this perspective, considering the demand for ethanol (44,223,400 L/year) to meet the B2 demand in the cooperative countries, which would generate $530,680.80 \mathrm{~m}^{3}$ of vinasse/year $(44,223,400 \cdot 12 / 1000)$ and an efficiency of generation of $42.2 \%$ and calorific value of $5136.5 \mathrm{kcal} / \mathrm{m}^{3}$, it would be possible to estimate the energy potential with the vinasse biogas (Equation (21)) [37].

$$
\mathrm{E}=530680.80 \cdot 11.5 \frac{\mathrm{m}^{3}}{\mathrm{day}} \cdot \frac{5136.5 \mathrm{kcal}}{\mathrm{m}^{3}} \cdot 0.422 \cdot \frac{4.184}{3600}=15385 \mathrm{MWh} / \text { year }
$$

This estimate was prepared based on data from CONAB [51] and the Embrapa Technological Information Agency [50]. It was also found that to meet the demand for B2 in the cooperative countries, 526,469 t of sugarcane would be necessary. This amount of sugarcane has the potential to generate 526,469 t of sugarcane bagasse, of which 70 to $80 \%$ is consumed in production processing and the remainder is destined for cogeneration of electricity. Considering the destination of $30 \%$ of sugarcane bagasse from the mandatory B2 mix, it would be possible to generate (15,794 MWh/year) of electric energy $(39,485 \mathrm{t}$ of bagasse $0.4 \mathrm{MWh} / \mathrm{t})$, as shown in Table 11.

Table 11. Energy indicators of the by-products from the production of anhydrous ethanol for biodiesel in the set of seven countries considered.

\begin{tabular}{cccccccc}
\hline BX & $\begin{array}{c}\text { Biodiesel } \\
\text { Demand } \mathbf{( m}^{\mathbf{3}} \mathbf{)}\end{array}$ & $\begin{array}{c}\text { Palm Oil } \\
\text { Cultivation } \\
\text { Area (ha) }\end{array}$ & $\begin{array}{c}\text { Demand for } \\
\text { Ethanol } \mathbf{( m}^{\mathbf{3}} \mathbf{)}\end{array}$ & $\begin{array}{c}\text { Ton of } \\
\text { Sugarcane } \\
\mathbf{( t )}\end{array}$ & $\begin{array}{c}\text { Biogas Energy } \\
\text { from Vinasse } \\
\mathbf{( M W h )}\end{array}$ & $\begin{array}{c}\text { Bagasse } \\
\text { Energy } \\
\mathbf{( M W h )}\end{array}$ & $\begin{array}{c}\text { Total } \\
\text { Energy } \\
\mathbf{( M W h}\end{array}$ \\
\hline B2 & 340,180 & 57,173 & 44,223 & 526,469 & 15,385 & 15,794 & 31,179 \\
B5 & 850,450 & 142,933 & 110,558 & $1,316,173$ & 38,462 & 39,485 & 77,947 \\
B6 & $1,020,540$ & 171,519 & 132,670 & $1,579,407$ & 46,154 & 47,382 & 93,536 \\
B7 & $1,190,630$ & 200,106 & 154,781 & $1,842,642$ & 53,847 & 55,279 & 109,126 \\
B8 & $1,360,720$ & 228,692 & 176,893 & $2,105,876$ & 61,539 & 63,176 & 124,715 \\
B9 & $1,530.810$ & 257,279 & 199,005 & $2,369,111$ & 69,231 & 71,073 & 140,304 \\
B10 & $1,700,900$ & 285,866 & 221,117 & $2,632,345$ & 76,924 & 78,970 & 155,894 \\
\hline \multicolumn{7}{c}{ Source: Table $9[37,50]}$.
\end{tabular}

The results presented in Table 11 reveal that the installation of agro-industrial production of biodiesel in the seven countries has great potential for generating secondary energy from by-products (vinasse biogas and electric energy from burning sugarcane bagasse), which can supply a wide energy demand from cities, companies, and families in the countries that participate in this cooperative production. Revenues from the sale of this energy produced by by-products can also contribute to the economic viability of biodiesel production.

\subsection{Location of Agro-Industrial Biodiesel Plants and Installation Investments in the Countries Participating in the Cooperation}

The experiences and knowledge produced by previous studies on biodiesel production initiatives in sub-Saharan African countries can contribute to the decision-making process on the business models to be adopted by the seven countries that will participate in the "multi-countries" initiative. Von Maltitz and Setzkorn [52] and Gasparatos et al. [10] identified and characterized four different types of biodiesel production projects in sub-Saharan countries: Type I projects (small-scale biofuel projects linked to cooperatives); Type II projects (large commercial farmers); Type III projects (subcontracted 
growers linked to commercial plantations or small farmers linked to biofuel processing plants or cooperatives); and type IV projects (large-scale commercial plantations).

For this study, the location of the biodiesel production plants was estimated from the demand for biodiesel by a member country of the established cooperation, as well as the availability of land for planting oilseeds. To estimate the location and number of processing plants, the Type II and III business models and projects proposed by Gasparatos et al. [10] and Von Maltitz and Setzkorn [52] were explored. Examples of two medium-sized biodiesel plants in operation in Brazil were also explored, which can produce $100 \mathrm{~m}^{3}$ of biodiesel/day and operate 333 days/year [53,54]. This made it possible to establish the number of industrial processing plants needed to supply the different biodiesel blends in the cooperative countries. To define the number of plants, the following indicators were used (Equation (22)):

$$
\text { No. of plants }=\frac{\text { Biodiesel demand } \mathrm{B} 100}{\text { Plant capacity } \mathrm{m}^{3} / \text { day }} \cdot(333 \text { days } / \text { year })
$$

For example, to calculate the number of plants needed to meet the demand for biodiesel established by the compulsory blend $\mathrm{B} 2$ in cooperative countries, the following equation would be used: No. of plants $(B 2)=\left(\left(340,180 \mathrm{~m}^{3} / 100 \mathrm{~m}^{3}\right.\right.$ day $) \cdot 333$ days $)=10$ agro-industrial units. This process was applied to the other biodiesel blends and the results can be seen in Table 12 .

Table 12. Number of plants to meet the demand for biodiesel in the cooperative countries.

\begin{tabular}{cccc}
\hline BX & B100 Biodiesel Demand $\left(\mathbf{m}^{\mathbf{3}}\right)$ & Capacity of the Agro-Industrial Biodiesel Plant $\left(\mathbf{m}^{\mathbf{3}} \mathbf{\text { Day) }}\right.$ & No. of Plants \\
\hline B2 & 340,180 & 100 & 10 \\
B5 & 850,450 & 100 & 26 \\
B6 & $1,020,540$ & 100 & 31 \\
B7 & $1,190,630$ & 100 & 36 \\
B8 & $1,360,720$ & 100 & 41 \\
B9 & $1,530,810$ & 100 & 46 \\
B10 & $1,700,900$ & 100 & 51 \\
\hline
\end{tabular}

Source: Elaborated with data from Tables 10 and 11 [53,54].

It is worth mentioning that, if the choice is made to adopt industrial plants with less or greater productive capacity $\left(100 \mathrm{~m}^{3} /\right.$ day), the number of plants will be greater or less than those shown in Table 12. In this study, we also chose to prioritize the location of the supply chain of the oilseeds (raw materials) and industrial processing plants to be close to major biodiesel consumption centers. In this sense, the mapping was elaborated for the optimized location of the installations of the biodiesel production units. However, one more country was included in this process (Tanzania) due to the availability of agricultural land and demand for consumption greater than Malawi, which could share biodiesel production plants, as shown in Table 13.

Table 13. Location of agro-industrial biodiesel plants in cooperative countries.

\begin{tabular}{ccccccccc}
\hline \multirow{2}{*}{ Country } & \multirow{2}{*}{ Biodiesel Demand (\%) } & \multicolumn{7}{c}{ Plant Units with a Capacity of $\mathbf{1 0 0} \mathbf{~ m}^{\mathbf{3}}$ /Day (333 Days/Year) } \\
\cline { 3 - 8 } & & B2 & B5 & B6 & B7 & B8 & B9 & B10 \\
\hline South Africa & $68 \%$ & 7 & 17 & 21 & 24 & 28 & 31 & 34 \\
Botswana & $3 \%$ & 0 & 1 & 1 & 1 & 1 & 1 & 2 \\
Malawi & $1 \%$ & 0 & 0 & 0 & 0 & 0 & 0 & 0 \\
Mozambique & $8 \%$ & 1 & 2 & 2 & 3 & 3 & 4 & 4 \\
Namibia & $3 \%$ & 0 & 1 & 1 & 1 & 1 & 1 & 1 \\
Tanzania & $11 \%$ & 2 & 3 & 4 & 5 & 5 & 6 & 6 \\
Zambia & $3 \%$ & 0 & 1 & 1 & 1 & 1 & 1 & 2 \\
Zimbabwe & $4 \%$ & 0 & 1 & 1 & 1 & 2 & 2 & 2 \\
Total & $100 \%$ & 10 & 26 & 31 & 36 & 41 & 46 & 51 \\
\hline
\end{tabular}

Source: Based on data from Tables 6 and 7 [53,54]. 
Table 13 shows that Botswana, Malawi, Namibia, and Zambia have very little demand for biodiesel, which would not justify the installation of an agro-industrial plant. In this context, these countries could act only in the production of the raw material and define a special quota for the acquisition of biodiesel, as well as priority for the commercialization of their raw materials for processing close to the major consumer centers. These countries may also choose to implement smaller processing plants, with a production capacity of up to $20 \mathrm{~m}^{3}$ /day of biodiesel, according to the business model and Type I Project (small-scale biofuel projects linked to cooperatives) proposed by Gasparatos et al. [10] and Von Maltitz and Setzkorn [52]. Considering also the geographical proximity, the demand for biodiesel, and the availability of land in South Africa, Mozambique, Tanzania, and Zimbabwe, these countries could consider the possibility of establishing production bases for the production of oilseeds and industrial plants for the production and cooperative consumption of biodiesel between them.

The optimized distribution of the location of the biodiesel agro-industrial units has the potential to reduce production costs and make biodiesel available in the local and regional markets of the countries participating in this initiative.

The initial cost of the industrial installation of biodiesel and equipment is estimated at US\$6,151,793 for each agro-industrial unit with a capacity of $100 \mathrm{~m}^{3} /$ day of biodiesel [54]. This value was extracted from a real agribusiness operating in Brazil, which has 200 direct employees [53]. The estimated revenue is US $\$ 0.90 / \mathrm{L}$ of biodiesel. In this sense, it would take 3 years to recover the investment per agro-industrial unit when using palm:

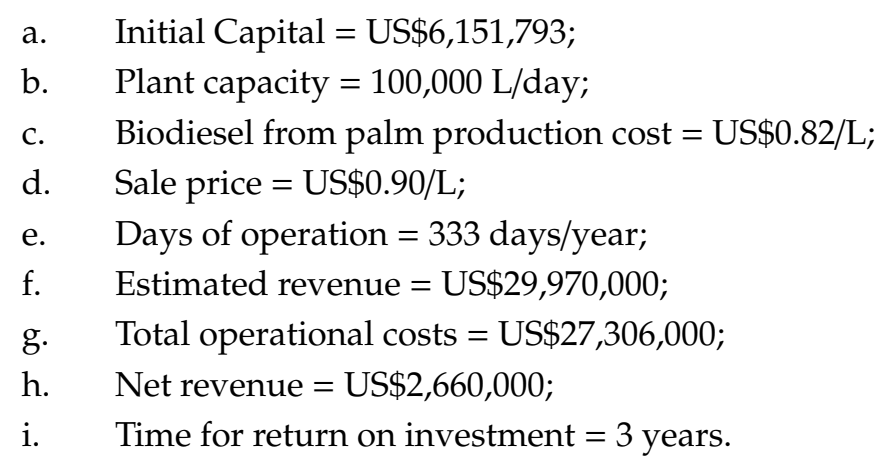

These estimates allow us to observe that the implementation of biodiesel agribusinesses with a production capacity of $100 \mathrm{~m}^{3} /$ day could be considered a medium-term investment, with an estimated return on capital of close to 3 to 5 years of operation (somewhat optimistic). Concerning investments in the industrial plant, the estimated US $\$ 6.1$ million above is close to, and between, the US\$5.0 and US\$12.0 million required investment identified by Romjin et al. [14] in countries in the sub-Saharan region, and can thus be exploited as a starting point for the formulation of policies, strategies, and investment decisions for the establishment of biodiesel production programs in sub-Saharan Africa.

\subsection{The "Multi-Countries" Model Implementation and Practical Issues}

The absence of decision-support tools can pose a risk in organizational decisions [55]. The operation research approach has gained representativeness in the scientific literature as an efficient method of supporting decision-making in the context of regional planning [21]. Thus, a first contribution of the model proposed and explored in this study consists of the development of mathematical programming that allows integrating and optimizing the available resources and their restrictions to support the decision-making processes of the productive base (agricultural and industrial), minimizing the costs of cooperative production of biodiesel in countries in the sub-Saharan African region.

The decision-support model proposed in this study considers the main oilseeds with potential for biodiesel production in sub-Saharan Africa (palm oil, jatropha, and sunflower) and explore some relevant variables and constraints considered in the evaluation of the feasibility of investment on biodiesel production: availability of area to be cultivated with palm, jatropha, and sunflower (ha); 
oil content from oilseed yield (L/ha); agricultural production cost per hectare of oilseed (US\$/ha); industrial processing costs (US\$/L); and demand for biodiesel $\left(\mathrm{m}^{3}\right)$.

The simulations and scenarios analyses reveal that palm oil is the oilseed that minimizes production costs to meet the different scales of production and demand for biodiesel (US $\$ 0.82 / \mathrm{L}$ ) while jatropha occupies the second position with an estimated cost of US\$1.05/L. To meet the biodiesel demand, the area needed for the agricultural production of jatropha would be approximately 3.1 times the area destined for palm oil and the production cost would be 1.3 times the cost of palm oil biodiesel. On the other hand, the capacity to generate jobs in the production of biodiesel from jatropha would be 5.0 times the capacity of palm oil. So, the scenario analyses identified that there is a trade-off in the criteria and decision process on which oilseed to use as raw material for the production of biodiesel: lower costs and smaller agricultural areas or greater generation of jobs. It will be necessary to build public and private strategies and policies to guide the investment decision-making process since both land resources (food production) and financial resources are notably scarce in the sub-Saharan region. The need to generate jobs and income is also part of the objectives, efforts, and investment for the development of sub-Saharan Africa. Thus, the decision will fall on (a) producing at lower costs (palm oil) or (b) choosing to generate a greater number of jobs (jatropha).

Another practical issue worth observing is the financial aspects of the implementation of the biodiesel production and consumption program in the sub-Saharan region. The simulations identified that the biodiesel from palm oil crop costs US $\$ 0.82 / \mathrm{L}$ and from jatropha costs US $\$ 1.05 / \mathrm{L}$. Considering the diesel price between US $\$ 0.60$ and US $\$ 1.14 / \mathrm{L}$ in the service station in the region in 2016, both the biodiesel produced from palm oil and jatropha will need subsidies and fiscal incentives (tax reductions) to be competitive in the fuel market (diesel). This way, the countries engaged in the "multi-countries" cooperation should design and implement strategies to get the financial resources to support the biodiesel production plant, investments, and the subsidies necessary to be competitive in the fuel market (diesel). In addition to its resources and the savings obtained by reducing diesel imports, some international agencies are relevant sources for financing activities that ensure the socio-economic and environmental development in sub-Saharan countries, for example, the World Bank, International Monetary Fund (IMF), Western African Economic Monetary Union (WAEMU), Economic Community of West-African States (ECOWAS), West African Development Bank (WADB), FAO, and the European Commission Fund (EuropeAid).

About the productive chain configuration, and considering the social, economic, and productive characteristics of countries and their strategies (producing with minimal costs or maximizing the generation of jobs), they can choose the business model that best suits their objectives, as proposed by Von Maltitz and Setzkorn [52] and Gasparatos et al. [10]. Type I and III projects are more geared toward job creation. Type II and IV projects are more oriented towards minimum production costs.

Finally, studies about bioenergy production initiatives in sub-Saharan Africa reveal that the lack of institutional frameworks to support the projects of biofuels in that region $[10,15,16,18,19]$ is an important source of uncertainties and cause of the projects' failures. Revisiting studies on the different biodiesel production initiatives in sub-Saharan Africa and exploring the successful experience of biodiesel production in Brazil, Ianda and Padula [56] suggest an institutional and organizational structure to support the implementation of biodiesel production programs in sub-Saharan Africa. The central elements of this structure can be explored, as a starting point, by the countries of the sub-Saharan region contemplated in the present study to organize and implement their biodiesel production and consumption programs using a cooperative "multi-countries" approach: (i) implementing a sustainable program that promotes social inclusion and the development of less-favored regions; (ii) structuring the value chain to produce feedstock and biodiesel processing plants, and thus strengthening the regional potential for biodiesel production; (iii) encouraging and supporting the creation of small cooperatives; (iv) implementing fiscal policies and tax reductions that stimulate agricultural and agro-industrial production; (v) establishing compulsory blending (B2, B5, B10, etc., 
with diesel) to provide and ensure a domestic market for biodiesel; (vi) guaranteeing competitive prices in the acquisition of raw material and the quality of the biodiesel; and (vii) promoting the agro-industrial sector in the context of the production of biodiesel and by-products.

\section{Concluding Remarks and Implications}

It has been shown that several biodiesel production initiatives in sub-Saharan Africa are not achieving the objectives set out in their projects due to the high production cost, which limits the growth of biofuel agribusinesses in this region and reduces the investment capacity in this segment. The small demand and high production costs in some sub-Saharan countries have compromised the economic feasibility of the biodiesel industry in the region. It was also found that the productive and economic feasibility is the main limitation in the implementation of biodiesel production projects, and it may be the main difficulty for decision-making when choosing oilseeds for the production of first-generation biodiesel. This way, it seems that the implementation of policies, strategies, and projects for cooperative "multi-countries" production and consumption of biodiesel can be an alternative to reverse these constraints. Thus, this study aimed to develop a model for the optimization of biodiesel production in Sub-Saharan Africa (SSA), with the objective function of minimizing the costs of biodiesel production using linear programming, taking into account local production restrictions.

The built optimization model allowed the identification of the characteristics and parameters of the production system that minimizes the costs of biodiesel production in South Africa and was later explored to contribute to the design of a biodiesel production and consumption configuration in a context of "multi-countries" cooperation between countries in the sub-Saharan region. The study showed that the production of biodiesel in sub-Saharan Africa can be optimized with the application of mathematical programming modeling. Preliminary projections and simulations made in South Africa identified that palm oil is the oilseed that minimizes production costs to meet the different scales of production and demand for biodiesel in that country (US\$0.82/L). Biodiesel from jatropha occupies the second position with an estimated cost of (US\$1.05/L). However, to produce and supply the biodiesel demand established by the B10 blend (10\% biodiesel and $90 \%$ diesel), the potential of job creation using jatropha is 5.0 times that of the palm oil seed. These results reveal the presence of trade-offs in the strategy, criteria and decision-making process about the choice between different oilseed crops: (a) to produce biodiesel from the crop with the minimal cost (palm oil) or (b) to choose the one that has the biggest potential of job creation (jatropha).

The analysis of the application of optimization modeling was extended to assess the viability of biodiesel production in a cooperative "multi-countries" manner in the region, especially those that share borders (South Africa, Botswana, Malawi, Mozambique, Namibia, Zambia, and Zimbabwe). The results of the forecasts carried out with computational resources reveal that, as in South Africa, palm oil is the most attractive oilseed (minimizes production costs) for the production of cooperative biodiesel among the seven countries selected in the survey. The volume of biodiesel to supply the B10 demand in 2031 has the potential to reduce US\$1.98 billion/year of the expenses on oil imports and diminish the reliance on imported oil in those seven sub-Saharan countries.

The installation of agro-industrial production of biodiesel also has great potential for generating electric energy from by-products (vinasse biogas and sugarcane bagasse), which can supply a wide energy demand from communities in countries that participate in this cooperative production. Revenues from the sale of energy produced by by-products can contribute to the economic viability of biodiesel production competitively compared to diesel exclusively from petroleum.

The implementation of biodiesel agro-industries with a production capacity of $100 \mathrm{~m}^{3} /$ day requires an investment of approximately US\$6.1 million with an estimated return on capital of close to 3 to 5 years of operation. As for the resources needed to finance biodiesel production initiatives and projects, in addition to their domestic financial capabilities, international agencies are the main sources of financing activities that guarantee socio-economic and environmental development in sub-Saharan countries. About the productive chain configuration, and considering the social, economic, 
and productive characteristics of countries and their strategies (producing with minimal costs or maximizing the generation of jobs), they can choose the business model that best suits their objectives, as proposed by Von Maltitz and Setzkorn [52] and Gasparatos et al. [10]. Type I and III projects are more geared toward job creation. Type II and IV projects are more oriented towards minimum production costs.

Studies about bioenergy production initiatives in sub-Saharan Africa reveal that the lack of institutional frameworks to support the projects of biofuels in that region is an important source of uncertainties and causes of the projects' failures. Thus, it will be necessary to design and implement an institutional and organizational structure to support the implementation of biodiesel production programs in sub-Saharan Africa. Ianda and Padula [56] suggest some elements for this institutional framework: "(i) structuring the value chain to produce feedstock and biodiesel processing plants, and thus strengthening the regional potential for biodiesel production; (ii) implementing fiscal policies and tax reductions that stimulate agricultural and agro-industrial production; (iii) establishing compulsory blending (B2, B5, B10) to provide and ensure a domestic market for biodiesel; (iv) guaranteeing competitive prices in the acquisition of raw material and quality of biodiesel". The central elements of this institutional structure can be explored, as a starting point, by the countries of the sub-Saharan region to organize and implement their biodiesel production and consumption programs in a cooperative "multi-countries" way.

Finally, it is worth highlighting the originality and the added value of this paper. This study provides academics, policymakers, and managers with policy and strategy implications. On one hand, from a multi-countries perspective, the decision-support model proposed in this study considers the main oilseeds with potential for biodiesel production in sub-Saharan Africa (palm oil, jatropha, and sunflower) and explore some relevant variables and constraints considered in the evaluation of the feasibility of investment in biodiesel production: availability of area to be cultivated with palm, jatropha, and sunflower (ha); oil content from oilseed yield (L/ha); agricultural production cost per hectare of oilseed (US\$/ha); industrial processing costs (US $\$ / \mathrm{L})$; and demand for biodiesel $\left(\mathrm{m}^{3}\right)$. Thus, this decision-support model can be exploited as a starting point for the formulation of policies, strategies, and investment decisions for the establishment of biodiesel production programs in sub-Saharan Africa. On the other hand, the literature on modeling the diversification of the energy matrix in SSA is still in its infancy, where the models of optimization of biofuel production used in most scientific works consider only a single country involved in the production and consumption of biofuel. Thus, this study adds to the perspective of modeling "multi-countries" cooperative production as a contribution to academic studies and the policymaking process of biofuel production systems.

Author Contributions: Conceptualization, T.F.I., E.A.S., A.N.N. and A.D.P.; methodology, T.F.I., E.A.S. and A.N.N.; software, E.A.S. and A.N.N.; formal analysis, T.F.I. and A.N.N.; investigation, T.F.I., E.A.S., A.N.N. and A.D.P.; resources, E.A.S., A.N.N. and A.D.P.; original draft preparation, T.F.I.; review and editing, T.F.I. and A.D.P.; supervision and project administration, E.A.S. and A.N.N. All authors have read and agreed to the published version of the manuscript.

Funding: This research received no external funding.

Acknowledgments: The authors thank the Brazilian agencies CAPES (Coordenação de Aperfeiçoamento de Pessoal do Ensino Superior) and CNPq (Conselho Nacional para o Desenvolvimento Científico e Tecnológico) for the scholarship and financial support in the development of this work and to the Graduate Program in Industrial Engineering at the Federal University of Bahia, for the technical support and infrastructure in conducting this research.

Conflicts of Interest: The authors declare no conflict of interest. 


\section{References}

1. ONU. Fatos Sobre Energia Sustentável. Rio+20. O Futuro Que Queremos. 2012. Available online: https://nacoesunid as.org/rio20-termina-e-documento-final-o-futuro-que-queremos-e-aprovado-com-elogios-e-reservas/ (accessed on 30 August 2019).

2. Corfee-Morlot, J.; Parks, P.; Ogunleye, J.; Ayeni, F. Achieving Clean Energy Access in Sub-Saharan Africa. A Case Study for the OECD. In UN Environment, World Bank Project: "Financing Climate Futures: Rethinking Infrastructure"; OECD: Paris, France, 2018; p. 4.

3. ECREEE. Plano de Ação Nacional no Setor das Energias Renováveis (PANER) da Guiné-Bissau Período 2015-2030; Centro para as Energias Renováveis e Eficiência Energética da CEDEAO (ECREEE): Praia, Cape Verde, 2017.

4. Ardayfio-Schandorf, E. The fuelwood/energy crisis in Sub-Saharan Africa. In Sustaining the Future. Economic, Social, and Environmental Change in Sub-Saharan Africa; Benneh, G., Morgan, B.W., Uitto, J.I., Eds.; United Nations University Press: Tokyo, Japan, 1996.

5. Map, W.B. World Statistics by Tables, Maps and Charts. Available online: http://world.bymap.org/ (accessed on 13 February 2019).

6. IEA. World Energy Outlook. Available online: https://www.iea.org/publications/freepublications/publicatio n/WEO2014.pdf (accessed on 18 July 2019).

7. Simabukulo, L.A.N.; Correa, L.F.S.d.; Santos, M.M.O.d.; Martins, M. Energia, industrialização e modernidade-História social. 2003. Available online: http://eletromemoria.fflch.usp.br/sites/eletrom emoria.fflch.usp.br/files/03.pdf (accessed on 11 September 2019).

8. ONU. Brasil é o Sétimo Maior Consumidor de Energia do Mundo, diz Banco Mundial; Organização das Nações Unidas: New York, NY, USA, 2013.

9. OECD/IEA Energy Use (kg of Oil Equivalent Per Capita) in the World. 2018. Available online: https: //data.worldbank.org/indicator/EG.USE.PCAP.KG.OE (accessed on 18 December 2018).

10. Gasparatos, A.; von Maltitz, G.P.; Johnson, F.X.; Lee, L.; Mathai, M.; De Oliveira, J.P.; Willis, K.J. Biofuels in sub-Sahara Africa: Drivers, impacts and priority policy areas. Renew. Sustain. Energy Rev. 2015, 45, 879-901. [CrossRef]

11. Haywood, L.; Von maltitz, G.P.; Setzkorn, K.A.; Ngepah, N. Biofuel Production in South Africa, Mozambique, Malawi and Zambia: A Status Quo Analysis of the Social, Economic and Biophysical Elements of the Biofuel Industry in Southern Africa; Council for Scientific and Industrial Research: Pretoria, South Africa, 2008.

12. Von Maltitz, G.P.; van der Merwe, M. Land and Agronomic Potential for Biofuel Production in Southern Africa; United Nation University UNU-WIDER: Helsinki, Finland, 2017; p. 58.

13. Sekoai, P.; Yoro, K. Biofuel Development Initiatives in Sub-Saharan Africa: Opportunities and Challenges. Climate 2016, 4, 33. [CrossRef]

14. Romijn, H.; Heijnen, S.; Rom Colthoff, J.; de Jong, B.; van Eijck, J. Economic and Social Sustainability Performance of Jatropha Projects: Results from Field Surveys in Mozambique, Tanzania and Mali. Sustainability 2014, 6, 6203-6235. [CrossRef]

15. Mulugetta, Y. Evaluating the economics of biodiesel in Africa. Renew. Sustain. Energy Rev. 2009, 13, 1592-1598. [CrossRef]

16. Salé, N.A.C.; Dewes, H. Opportunities and challenges for the international trade of Jatropha curcas-derived biofuel from developing countries. Afr. J. Biotechnol. 2009, 8, 515-523.

17. Van Eijck, J.; Smeets, E.; Faaij, A. The economic performance of jatropha, cassava and Eucalyptus production systems for energy in an East African smallholder setting. GCB Bioenergy 2012, 4, 828-845. [CrossRef]

18. Jingura, R.M.; Kamusoko, R. A multi-factor evaluation of Jatropha as a feedstock for biofuels: The case of sub-Saharan Africa. Biofuel Res. J. 2015, 2, 254-257. [CrossRef]

19. Slingerland, M.; Schut, M. Jatropha Developments in Mozambique: Analysis of Structural Conditions Influencing Niche-Regime Interactions. Sustainability 2014, 6, 7541-7563. [CrossRef]

20. Hillier, F.S.; Lieberman, G.J. Introdução à Pesquisa Operacional, 5th ed.; Brasil, M.H., Ed.; McGraw Hill Brasil: Porto Alegre, Brazil, 2010; p. 1006.

21. Ilbahar, E.; Cebi, S.; Kahraman, C. A state-of-the-art review on multi-attribute renewable energy decision making. Energy Strategy Rev. 2019, 25, 18-33. [CrossRef]

22. Balaman, S.Y.; Selim, H. Sustainable design of renewable energy supplu chains integrated with district heating systems: A fuzzy optimization approach. J. Clean. Prod. 2016, 133, 865-885. [CrossRef] 
23. Cai, Y.P.; Huang, G.H.; Yang, Z.F.; Lin, Q.G.; Tan, Q. Community-scale renewable energy systems planning under uncertainty-An interval chance-constrained programming approach. Renew. Sustain. Energy Rev. 2009, 13, 721-735. [CrossRef]

24. Pienaar, J.; Brent, A.C. A model for evaluating the economic feasibility of small-sacale biodiesel production systems. Renew. Energy 2012, 39, 483-489. [CrossRef]

25. Akella, A.K.; Sharma, M.P.; Saini, R.P. Optimum utilization of renewable energy sources in a remote area. Renew. Sustain. Energy Rev. 2007, 11, 894-908. [CrossRef]

26. Demczuk, A.; Padula, A.D. Using system dynamics modeling to evaluate the feasibility of ethanol supply chain in Brazil: The role of sugarcane yield, gasoline prices and sales tax rates. Biomass Bioenergy 2016, 97, 186-211. [CrossRef]

27. Viet, D.T.; Phuong, V.V.; Duong, M.Q.; Khanh, P.; Kies, A.; Schyska, B. A cost-optmal pathway to integrate renewable energy into the future Vietmanese power system. In Proceedings of the 4th International Conference on Green Technology and Sustainable Development (GTSD), Ho Chi Minh City, Vietnam, 23-24 November 2018; pp. 144-149.

28. Duong, M.Q.; Nguyen, H.H.; LE, T.L.; Mussetta, M. New Planning for the 500kV Vietnamese Grid with High Penetration of Renewable Energy Sources. In Proceedings of the 2019 IEEE-Milan PowerTech, Milan, Italy, 23-27 June 2019.

29. Ramakumar, R.; Sudhakara shetty, P.; Ashenayi, K. Linear programming appproach to the design of integrated renewable energy systems for developing countries. IEEE Trans. Energy Convers. 1986, EC-1, 18-24. [CrossRef]

30. Rubem, A.P.D.S.; Soares de Mello, J.C.C.B.; Angulo Meza, L. A goal programming approach to solve the multiple criteria DEA model. Eur. J. Oper. Res. 2017, 260, 134-139. [CrossRef]

31. Hira, D.S. Operations Research; S. Chand Publishing: New Delhi, India, 1992.

32. SEBRAE. Biodiesel. Available online: https://www.agencia.cnptia.embrapa.br/Repositorio/NT00035116_000 gihb7tn102wx5ok05vadr1szzvy3n.pdf (accessed on 5 May 2020).

33. Lôbo, I.P.; Ferreira, S.L.C.; Cruz, R.S. Biodiesel: Parâmetros de qualidade e métodos analíticos. Quim. Nova 2009, 32, 1596-1608. [CrossRef]

34. Systems, L. Excel Add-In for Linear, Nonlinear, and Integer Modeling and Optimization. Available online: https://www.lindo.com/ (accessed on 23 July 2019).

35. Statistics, I.E. Biofuels Production and Consumption. Available online: http://southafrica.opendataforafrica.or g/nhbrxod/biofuels-production-and-consumption?country=South\%20Africa (accessed on 6 February 2018).

36. AQUASTAT, F. Arable Land. Available online: http://www.fao.org/nr/water/aquastat/data/query/index.htm 1?lang=en (accessed on 13 February 2019).

37. Gehring, C.G. Análise da geração de energia elétrica a partir do biogás produzido na fermentação anaeróbica de vinhaça. Ph.D. Dissertation, Escola de Engenharia de São Carlos, Universidade de São Paulo: São Carlos, Brasil, 2014; p. 124.

38. Dos Santos Alves, C.E.; Belarmino, L.C.; Padula, A.D. Feedstock diversification for biodiesel production in Brazil: Using the Policy Analysis Matrix (PAM) to evaluate the impact of the PNPB and the economic competitiveness of alternative oilseeds. Energy Policy 2017, 109, 297-309. [CrossRef]

39. CEPLAC. Dendê. Available online: http://www.ceplac.gov.br/radar/dende.htm (accessed on 14 April 2020).

40. Economy, G. Ranking Diesel Prices Africa. Available online: https://www.theglobaleconomy.com/rankings/ diesel_prices/Africa/ (accessed on 26 February 2020).

41. Padula, A.D.; Santos, M.S.; Ferreira, L.; Borenstein, D. The emergence of the biodiesel industry in Brazil: Current figures and future prospects. Energy Policy 2012, 44, 395-405. [CrossRef]

42. Gerpen, J.V. Biodiesel processing and production. Fuel Process. Technol. 2005, 86, 1097-1107. [CrossRef]

43. Transnet, S.L. Integrated Report; Transnet: Johannesburg, South Africa, 2017.

44. FAO. Bioenergy and Food Security Rapid Appraisal (BEFS RA); United Nations Food and Agriculture Organization: Rome, Italy, 2014; p. 50.

45. FGV. Projeto Potencialidades Regionais Estudo de Viabilidade Econômica Dendê; Fundação Getúlio Vargas: São Paulo, Brazil, 2003; p. 39.

46. MAPA. Diagnóstico da Produção Sustentável da Palma de Óleo no Brasil/Ministério da Agricultura Pecuária e Abastecimento; Ministério da Agricultura, Pecuária e Abastecimento: Brasília, Brazi, 2018; p. 58. 
47. Zambrano, F.; Delgado, K.; Silva, H.; Nomura, R.B.; Souza, D.; Andrade, C.Z. Extração e avaliação do óleo de pinhão manso (Jatropha Curcas 1.) oriundo das cercas vivas de Manabí Equador. Rev. Bras. Energ. Renov. 2015, 4, 55-70. [CrossRef]

48. UNDATA. A World of Information. Gas Oil/ Diesel Oil. Available online: http://data.un.org/Data.aspx?d= EDATA\&f=cmID\%3ADL (accessed on 18 November 2019).

49. Santos, M.S.D.; Ianda, T.F.; Padula, A.D. Bioenergy as a means to social and economic development in Guinea-Bissau: A proposal for a biodiesel production and use program. Int. J. Sustain. Dev. World Ecol. 2014, 21, 495-502. [CrossRef]

50. EMBRAPA. Árvore do Conhecimento Cana-de-açúcar. Energia Elétrica. Available online: http://www.agen cia.cnptia.embrapa.br/gestor/cana-de-acucar/arvore/CONTAG01_131_22122006154842.html (accessed on 2 June 2020).

51. CONAB. Acompanhamento da Safra Brasileira-SAFRA 2018/19; Companhia Nacional de Abastecimento: Brasilia, Brazil, 2018.

52. Von Maltitz, G.P.; Setzkorn, K.A. A typology of Southern African biofuel feedstock production projects. Biomass Bioenergy 2013, 59, 33-49. [CrossRef]

53. Cibiense, G.V.L. Dados da Empresa. Available online: https://www.caibiense.com/ (accessed on 4 June 2020).

54. ANP. Boletins ANP_Fevereiro 2017; Agência Nacional de Petróleo, Gás Natural e Biocombustíveis: Rio de Janeiro, Brazil, 2017.

55. Simon, H.A. A behavioral model of rational choice. Q. J. Econ. 1955, 69, 99-118. [CrossRef]

56. Ianda, T.F.; Padula, A.D. Exploring the Brazilian experience to design and simulate the impacts of a biodiesel program for sub-Saharan countries: The case of Guinea-Bissau. Energy Strategy Rev. 2020, 32. [CrossRef]

(C) 2020 by the authors. Licensee MDPI, Basel, Switzerland. This article is an open access article distributed under the terms and conditions of the Creative Commons Attribution (CC BY) license (http://creativecommons.org/licenses/by/4.0/). 